This is an Accepted Manuscript of an article published by Taylor \& Francis in South East Asia Research on 21 Aug 2019, available online: $h$ ttps://doi.org/10.1080/0967828X.2019.1642027

Accepted version downloaded from SOAS Research Online: http://eprints.soas.ac.uk/31505/

\title{
A research agenda for studying legislative incumbent turnover in new democracies, using Indonesia as a case study
}

Michael Buehler

SOAS University of London, UK

mb107@soas.ac.uk

Ronnie Nataatmadja

Institutional Effectiveness, Planning and Research, College of Lake County, USA

rnataatmadja@clcillinois.edu

\begin{abstract}
Legislative incumbent turnover rates are an important indicator for the quality of a democracy. Low turnover rates may indicate the presence of oligarchic structures while high turnover rates may be a sign of political instability. Yet, there is little research on incumbent turnover in new democracies. This article will suggest ways to address this gap in the literature by looking at Indonesia. The country is not only the third largest democracy in the world but also a relatively new democracy that has only conducted four elections since 1998.

The lack of studies on incumbent turnover in new democracies is mirrored in the literature on Indonesia. The vast scholarship on democratization in Indonesia that has emerged over the past twenty years has yet to harness the insights to be gained from examining legislative incumbent turnover rates. The goal of this article is twofold: One, to present for the first time a systematic and comprehensive account of incumbent turnover rates in Indonesia across all election cycles since 1998. Two, to sketch an agenda for future research on incumbent turnover in Indonesia and other new democracies and facilitate such research by making publicly available an original dataset on incumbent turnover in Indonesia. ${ }^{1}$
\end{abstract}

Key words: Democratization, Elections, Incumbent turnover, Indonesia, New Democracies, Political Elites

Incumbent turnover rates have been called an important "seismograph" for the quality of democracy (Best et al. 2000, 185). A “normal” turnover rate lies between 20\% and 40\%. 
Turnover rates below 20\% "mark a limit below which oligarchic structures can develop.” Turnover rates above 90\% are associated with "regime discontinuity with complete or near complete changes of the political order” (Gouglas et al. 2018, 3). In short, "the question of parliamentary turnover feeds into the wider concern of elite turnover” (Abel and Grossman 2015, 458).

Incumbent turnover rates not only illuminate the contours of democratization but also shed light on more specific questions related to the quality of democracy, including the role political parties play in elite turnover (Hazan and Rahat 2006) and how turnover rates shape the policymaking process (Kuklys 2013).

In light of the usefulness of knowing turnover rates for our understanding of democratization, it is surprising that no systematic account of turnover rates in Indonesia, the world's third largest democracy after India and the United States, exists. To some degree, this simply reflects the fact that research on incumbent turnover in new democracies is almost non-existent. Most research on incumbent turnover focuses on the USA (see Moncrief et al. 2004 for an overview). There is also a small literature on incumbent turnover in Western Europe (see Gouglas et al. 2018 for an overview).

In addition to this bias in the broader literature towards incumbent turnover in the USA and, to some degree, Western Europe, a systematic and comprehensive account of incumbent turnover in Indonesia may also be missing due to the difficulties of collecting data. The only study on it in Indonesia was published after the Indonesian National Election Commission published online data on candidates running in the 2014 legislative elections. In its concluding section, the study lamented a "lack of systematic data" on incumbent turnover rates in Indonesia as a detriment to further research (Dettman et al. 2017, 28).

To address this gap in the literature and to facilitate future research in Indonesia and other new democracies, we will first provide comprehensive data on incumbent turnover for Indonesia's elections since 1999. We will then identify patterns in these descriptive statistics and discuss how they can be used as stepping stones towards more in-depth research.

\section{A lack of incumbent turnover studies}

Twenty years after the collapse of the New Order regime, incumbent turnover in Indonesia's legislative elections remains grossly under-researched. Occasionally, turnover rates are mentioned in the literature (Mietzner 2009, 144) but without any critical discussion of how they were measured and how these results were obtained. These accounts are therefore merely anecdotal. To the best of our knowledge, there is only one systematic study of 
incumbent turnover in Indonesia. However, it examines turnover only for the Indonesian national parliamentary elections in 2014 because it relies on an online dataset made available by the National Election Commission that year (Dettman et al. 2017). In short, our article provides the first systematic account of incumbency turnover over multiple election cycles in Indonesia.

In the following paragraphs, we explain how we defined and measured incumbent turnover. We then identify patterns in turnover rates before discussing how our findings can be used for future research.

\section{Definition of turnover, levels of measurement, and data collection}

How turnover is defined and at what level it is measured determines research results (Abel and Grossman 2015, 458). Hence, we first explain how we defined incumbent turnover.

\section{Defining incumbent turnover}

Any new parliament consists of re-elected and incoming legislators. The latter group is a mix of parliamentarians who have never sat in parliament before, so-called first-timers, and parliamentarians who did not occupy a seat in the previous parliament but may have been a member of parliament (MP) at some other point in the past.

We do not differentiate between first-timers and MPs who occupied a seat in parliament before the previous legislative period. Instead, we simply report incoming legislators because this is the standard approach in the scholarly literature on incumbent turnover (Abel and Grossman 2015, 458). This will make our findings directly comparable to the broader literature, which defines incumbent turnover "as the proportion of newcomers, including both first-time and re-entering MPs, as a share of the total membership of a new legislative assembly” (Gouglas et al 2018, 4).

However, one needs to be aware of the potential bias the conflation of newcomers and re-entering MPs introduces to measuring incumbent turnover rates. A legislator who sat in the national parliament between 1999 and 2004, then acted as governor between 2004 and 2014, but re-entered national parliament in 2014, is theoretically not a "new candidate." 2 This is particularly relevant for research in new democracies such as Indonesia. In many new democracies the state continues to dominate the economy and corruption and rent-seeking are endemic and systemic. In such contexts, proximity to the state is crucial to personal advancement and enrichment. Hence, any political post is better than no political post. This environment leads to very specific career patterns. Concretely, Indonesian politicians 
frequently rotate between national and subnational parliaments and also between executive and legislative branches of government because they need to stay "inside" the state at all cost. $^{3}$ The number of re-entering MPs may therefore be higher in new democracies such as Indonesia than in consolidated Western democracies.

Focusing on incoming candidates only, and in line with other existing literature on turnover rates, we therefore measured, strictly speaking, "the effects of political alternation rather than the renewal of the legislature” (Abel and Grossman 2015, 459). ${ }^{4}$ It is thus more accurate to speak of elite circulation than elite turnover. In any case, focusing on incoming candidates only does not affect the validity of turnover rates between consecutive election cycles, which is the main point of comparison throughout the article.

\section{Measuring incumbent turnover}

The level of analysis at which turnover rates are reported also influences research findings. Turnover rates can be reported for individual candidates, political parties or entire parliaments. Examining turnover rates at the individual level would not have allowed us to identify broader patterns in elite circulation but would merely have led to a study on career strategies of individual politicians (King 1991). Similarly, reporting turnover rates at the parliamentary level would have led to a loss of important information. For example, Party A and Party B may have had incumbent turnover rates of 30\% and 10\% respectively in the 2004 elections but Party A and Party B then had incumbent turnover rates of $10 \%$ and $30 \%$ in the 2009 elections. While the overall turnover rate measured at the parliament level remains the same, important changes have occurred at the party level. In light of these considerations, reporting turnover rates at the party level seemed most appropriate for our interest in elite circulation in Indonesia.

There are additional hurdles to studying legislative incumbent turnover in new democracies. Politics in Indonesia and other new democracies is largely non-programmatic. Political parties, in other words, rarely represent distinct political ideologies. In addition, party systems are usually poorly institutionalized (Hicken 2006). A lack of ideological platforms and resources explain why a higher number of candidates switch parties from one election cycle to another compared to established democracies in the West (O’Brien and Shomer 2013).

Since party switching is less common in consolidated democracies, it is rarely discussed in the literature on incumbent turnover, and various experts advised us not to count party switchers as turnover points. ${ }^{5}$ To be in line with standard practice with existing 
research, we treated incumbents who switched parties before elections just as any other incumbent. At the end of this article, we will discuss what high levels of party switching may mean for incumbent turnover rates.

\section{Data collection}

Electoral incumbent turnover data may be collected by comparing the names of parliamentarians at the end of a given legislative session with the names of parliamentarians at the beginning of the next legislative session. However, such an approach would miss seats that have been turned over through mid-session exits. To avoid such bias we relied on Moncrief's method, which obtains turnover rates by comparing "the membership at the beginning of the session immediately after election $t$ with the membership immediately after the election at $t+1$ ” (Moncrief et al. 2004, 361). In line with this method, we calculated incumbent turnover based on the official lists of MPs that the Indonesian National Election Commission publishes after each election. Many of these lists were available only in hardcopy or pdf format. Hence, we entered all list data into an excel sheet, and, as we did so, corrected misspellings and made note if the same candidate name was spelled differently across lists and/ or elections. Since many Indonesians do not use family names, we consulted various sources to triangulate data on the identity of candidates and MPs from as many vantage points as possible. We compared handbooks about MPs published by the Indonesian national parliament, the Kompas newspaper archive, which compiles the curricula vitae of MPs and many candidates, and data from the Secretariat General office of the national parliament. As a last resort, we examined newspaper articles to verify candidates’ identity. We have made our dataset set available for future research in an online appendix. [link here to supplementary material]

Having verified the identity of candidates and MPs, we calculated both non-electoral and electoral incumbent turnover. To establish non-electoral turnover rates, that is, the number of MPs dropping out before the elections, we compared the names of all MPs in a given parliament with all the candidate names on party lists submitted to the National Election Commission for the subsequent election. For example, we compared the names of all MPs in the 1999-2004 parliament with the names of candidates running in the 2004 elections. To determine electoral turnover rates, we compared the lists of MPs published by the Indonesian National Election Commission after each election. For example, we compared the lists of MPs elected in 1999 with the list of MPs elected in 2004 to calculate how many MPs in the 2004-2009 parliament were newcomers. It is important to mention that there is a 
short time lag between the elections and the publication of these official MP lists. The MP list resulting from the 7 June 1999 election was published on 1 September 1999. The MP list resulting from the 5 June 2004 election does not state a publication date. The MP list resulting from the 9 April 2009 election was published on 2 September 2009. The MP list resulting from the 9 April 2014 election was published on 9 May 2014. ${ }^{6}$ Theoretically, elected members of parliament could have exited politics before they were registered in the membership lists. The time lag between elections and the publication date of our data sources may therefore lead to an underrepresentation of turnover rates. However, we believe that this risk of underreporting incumbent turnover is minuscule as the time lag between elections and the publication of these official MP lists consists of a few months at most.

\section{Findings}

An overview of non-electoral and electoral incumbent turnover rates in Indonesia's national legislative elections since 2004 is shown in Table 1.

\section{[4.1] Non-electoral incumbent turnover}

Non-electoral incumbent turnover has steadily declined since the 1999 elections. 40.5\% (187/462), 36.5\% (201/550) and 16.6\% (93/560) of MPs did not make it back on candidate lists for the 2004, 2009 and 2014 elections respectively.

Non-electoral incumbent turnover also dropped sharply when compared within parties across election years. Most extreme in this respect is the PKB. While 52.9\% (27/51) of PKB incumbents from the 1999-2004 parliament were no longer running in the 2004 elections, only 7.1\% (2/ 28) of all PKB incumbents from the 2009-2014 parliament disappeared from PKB's list prior to the 2014 elections.

Comparing non-electoral incumbent turnover across parties within a given election year is problematic as some parties, especially before the consolidation ${ }^{7}$ of the party system in the mid-2000s, had only very few MPs. Their non-electoral turnover figures therefore look very high compared to larger parties with more MPs. However, a comparison of the six parties that have consistently had MPs in the national assembly since 1999 shows that the PPP has one of the highest non-electoral turnover rates prior to each election. Meanwhile, the PKS is the only party that has consistently had one of the lowest non-electoral turnover rates since 2004, as shown in Table 1.

\section{[4.2] Electoral incumbent turnover}


Our findings show that since 2004 electoral incumbent turnover has been fairly stable at high levels. 49.4\% (136/ 268), 56.2\% (196/ 349) and 49.7\% (232/467) of all MPs who ran for reelection failed to win a seat in the 2004, 2009 and 2014 elections respectively. ${ }^{8}$

We also wanted to know whether incumbents were defeated by candidates from their own party or from other parties. On average, 26.6\% (291/1091) of all incumbents standing for re-election between 1999 and 2014 were defeated by candidates from their own party. 25\% (270/1084) of all incumbents standing for re-election between 1999 and 2014 lost their seat to a candidate from another party. However, incumbent turnover through partisan defeat increased steadily over the years. 22.2\% (61/275), 24.4\% (85/349) and 27.2\% (127/467) of incumbents were defeated by candidates from other parties in the 2004, 2009 and 2014 elections respectively. Meanwhile, 27.3\% (75/275), 31.8\% (111/349) and 22.5\% (105/467) of all incumbents who were running for re-election were defeated by co-partisans in 2004, 2009 and 2014 respectively, as shown in Table 1.

In short, partisan defeat has replaced intrapartisan defeat as the main reason for electoral incumbent turnover.

\section{Situating our findings in the broader literature and identifying avenues for future research}

In the remaining paragraphs, we want to link the incumbent turnover patterns identified above with existing research on the causes of turnover. This will allow us to identify promising avenues for future research into the causes of incumbent turnover in Indonesia in particular and other new democracies in general. We are currently conducting field research in Indonesia on some of these issues and will report our findings in a separate paper.

Supply-and-demand models of incumbent turnover (Norris 1997; Best et al. 2000; Gouglas et al. 2018, 4) provide an ideal starting point to develop a research agenda that will examine in a systematic fashion the causes of incumbent turnover in Indonesia and other new democracies. Such models categorize the causes for incumbent turnover as follows. On the one hand (supply-side), incumbents drop out of politics because they die; because they are forced to step down due to arrest or a scandal; or because they leave politics voluntarily. On the other hand (demand-side), a seat may turn over because an incumbent fails to secure a nomination from her party prior to elections, a process called “deselection” (Matland and Studlar 2004, 94); or because she fails to get re-elected by voters, as shown in Figure 1. 


\section{1 Supply-side causes of incumbent turnover}

Assuming that death in office and arrests of incumbents are too rare to account for more than a fraction of non-electoral incumbent turnover, the decline we identified in Table 1 may indicate a growing attractiveness of being an MP. Therefore, fewer incumbents dropped out voluntarily before the elections in 2014 than in 2009 and 2004. Factors that motivate incumbents to seek re-election are financial compensation for being an MP, perks that come with career continuity and prospects for material advancement (through legal and illegal means) (Borchert 2011; Gouglas et al. 2018, 6). There are also characteristics of legislative institutions that may influence incumbent turnover rates prior to elections (Heinsohn and Freitag 2012, 359). For instance, legislative institutionalization shapes non-electoral incumbent turnover (Matland and Studlar 2004). Concretely, the more support lawmakers receive from a well-funded parliamentary infrastructure, the less likely they are to resign due to exhaustion or frustration. Furthermore, studies also mention the productivity and effectiveness of parliaments as determinants of turnover rates. Incumbents find it more appealing to remain in a parliament that is pursuing its agenda effectively and which is capable of defending its interests vis-à-vis other government branches. In contrast, weak parliaments that are overpowered by other branches of government see higher turnover rates because some incumbents quit out of frustration over their relative lack of power (Heinsohn and Freitag 2012, 360). Finally, in countries where double-listings are allowed, turnover rates tend to be lower because incumbents reduce their risk of deselection and electoral defeat by running in more than one constituency (Matland and Studlar 2004, 105).

In light of these findings, future research on non-electoral incumbent turnover in Indonesia will have to examine if, and if so, how, financial compensation motivates incumbents to seek re-election. Compared to democracies in the West, informal compensation is likely to influence the supply of incumbents too, given the fact that corruption and rent-seeking remain endemic and systemic in Indonesian politics. At the same time, a more assertive government stance against corruption may deter incumbents from seeking re-election, ${ }^{9}$ or lead to higher arrest numbers and subsequent drop-out or deselection. ${ }^{10}$

Furthermore, future research will have to examine to what degree the aforementioned institutional determinants of non-electoral turnover apply to Indonesia. For instance, candidates can only run in one district. Hence, double-listings cannot explain variance in preelection incumbent turnover rates across time. With regard to parliamentary capacity, the Indonesian national parliament has become more assertive over the years vis-à-vis other 
government branches (Sherlock 2007, 4). Incumbents in Indonesia are therefore unlikely to forego re-election because they are frustrated by a lack of power. Likewise, state support for parliamentarians has improved considerably in recent years ${ }^{11}$ even though the institutionalization of the Indonesian national parliament continues to be below par (Adiputri 2015).

In any case, even if one were to assume that working as a legislator in Indonesia's national parliament is challenging because of executive government dominance in Indonesian politics and low levels of institutional support, we do not believe that these challenges are serious enough to account for a significant number of incumbents to voluntarily leave politics prior to elections. Based on the fact that the Indonesian legislature issues only a very low number of laws each year, scholars have suggested that the Indonesian parliament is primarily a place where rent-seekers meet to discuss potential deals (Ziegenhain 2008a, 45). In such an environment, monetary rewards associated with a seat in the national parliament arguably trump concerns about institutional support available to parliamentarians or parliamentary power vis-à-vis other government branches when Indonesian legislators consider whether or not to run again for a seat in parliament.

Future research needs to examine how Indonesia’s multi-layered political system and its poorly institutionalized party system shape incumbent turnover. As mentioned above, our dataset of incumbent curricula vitae suggests that Indonesian politicians frequently move between government layers throughout their careers. Future research on the supply-side causes of incumbent turnover in Indonesia will therefore also have to look at if, and if so how, the presence of subnational elections (and therefore additional political marketplaces that provide national level MPs with an exit option) shape MPs decision to seek or abstain from re-election. In other words, do some incumbents refrain from running in national elections because they see a higher chance of winning elections at the local level? Likewise, future research should examine how many former MPs re-enter national politics from a subnational post in an election year.

Finally, future research needs to examine the number of MPs that switch parties prior to elections and whether this is a viable strategy to get re-elected. As mentioned in the introduction, new democracies such as Indonesia have higher numbers of MPs switching parties than consolidated democracies in the West. Whether high numbers of party switchers increase incumbent turnover rates and what it means for the quality of a democracy needs to be examined in future studies. A preliminary analysis we conducted on the electoral fate of party switchers indicates that most failed to get re-elected, as shown in Table 2. 
Whether most party switchers fail to get re-elected because these incumbents did not receive any support from their new parties or whether voters punished them for switching parties requires further examination. The broader relevance of our findings regarding party switching incumbents in Indonesia doing poorly at the ballot box is that party switching may increase incumbent turnover rates in new democracies. In fact, an expert on incumbent turnover in Western democracies we consulted suggested that party switching of incumbents is likely to become more prevalent in consolidated democracies too, given the rise of populism and the accompanying erosion of traditional party alliances. ${ }^{12}$ Future research on incumbent turnover will therefore have to pay more attention to the potential implications party switching may have on incumbent turnover rates and elite circulation more broadly.

\section{[5.2] Demand-side causes of incumbent turnover}

There are also demand-side causes for incumbent turnover, as mentioned in Figure 1. Concretely, candidate de-selection by party leaders and voters withdrawing their support for incumbents on Election Day shape both non-electoral and electoral turnover. In Indonesia, the picture is complicated by the fact that the electoral system has changed considerably over the past twenty years, with potential consequences for candidate de-selection and voter behaviour.

In the following paragraphs we will therefore briefly examine the main changes to the electoral system since 1999, before looking at how de-selection and voter behaviour has shaped incumbent turnover over past election cycles.

Changes in the electoral system since 1999

In the 1999 elections, citizens could only vote for a party. Party leaders then selected MPs from a list of nominees from the electoral district in which the party had achieved its best results. ${ }^{13}$ After the 1999 elections, civil society organizations and foreign donor agencies criticized Indonesia's electoral framework for favouring candidates who had strong relations with party leaders but lacked genuine grassroots support, thereby perpetuating the dominance of “old elites” over Indonesia’s centralized political party structures.

In an effort to deepen democratization, the government replaced Legislative Election Law No 3/1999 with Legislative Election Law No 12/2003 prior to the 2004 parliamentary elections. Now, voters had to choose a party and were given the possibility of picking a candidate from that party. In other words, the party vote was mandatory while the preference vote was optional. A candidate was elected regardless of her ranking on the party list if she 
surpassed $100 \%$ of a divisor, which was calculated by dividing the total number of votes in an electoral district by the total number of seats available in that district (Hare-quota).

In March 2008, the legislature adopted Legislative Election Law No 10/2008. Once again, the intention was to curb the authority of party leaders and empower ordinary citizens in the 2009 elections. Unlike in 2004, voters could only tick one box in 2009, either for a party or for a candidate. If they voted for a candidate, this vote would automatically also be counted as a vote for the party that had nominated that candidate. ${ }^{14}$ In addition, the law stated that seats were to be allocated based on the proportion of total party votes and preference votes won in each district. In other words, the National Election Commission would determine who would occupy the seats won by each party based on the preference votes each candidate from these parties had received.

In December 2008, only five months before the legislative elections, the Constitutional Court intervened in a way that dramatically reshaped the electoral system. Specifically, the Constitutional Court annulled the 30\% divisor stipulated in Law No 10/2008 and mandated that seat allocation take place solely based on preference vote tally, regardless of ballot rank. Parties would still submit ordered lists of candidates to voters and the number of total preference and party votes would still determine how many legislative seats the party would occupy. However, only the number of votes a candidate received would determine if she were to secure a legislative seat. The Constitutional Court decision therefore created an open party list system. This completed the shift under way since 1999 from a highly partycentred election system to a highly candidate-centred election system.

Legislative Election Law No 28/ 2012 was adopted in April 2012 to regulate the 2014 elections. The new law did not contain any significant changes and preserved the open party list system introduced in 2009. Concretely, Indonesian citizens were again asked to either vote for a party or select their preferred candidate from a list, which then counted as a vote for that candidate as well as her party. As in 2009, the Electoral Commission then calculated the number of seats each party had won in each electoral district. These seats where then allocated to candidates based on the number of preference votes (Nehru and Bulkin 2013). [5.2.i] Incumbent turnover through candidate de-selection

An important determinant of incumbent turnover is de-selection by an incumbent's party, as shown in in Figure 1. In many democracies, more incumbents are de-selected by their parties than voted out of office by the electorate (Gouglas et al. 2018).

Unfortunately, the data sources we relied on - official lists of members of parliament published by the National Election Commission - did not allow us to identify whether the 
369 incumbents who exited politics prior to elections between 2004 and 2014 did so voluntarily or against their will. Since our data shows how many incumbents dropped out prior to elections, without providing any further information why they left politics (death; arrest/ scandal; de-selection), future research will first have to establish what percentage of non-electoral incumbent turnover occurs due to de-selection. This requires a shift from examining incumbent turnover at the party level to the level of candidates. Personal interviews, focus groups and surveys among incumbents and party leaders responsible for candidate selection will have to be conducted. In a second step, future research will have to examine if, and if so, why incumbent turnover due to de-selection has decreased over the years in contrast to incumbent turnover rates due to deselection of candidates in consolidated democracies.

Since death in office and forced resignations during sessions are relatively rare in Indonesia $^{15}$, we assume that most involuntary exits prior to elections occur because parties refuse to re-nominate incumbents. The decline in non-electoral incumbent turnover because of de-selection in past years may be interpreted in two different ways: One, political parties have become more consolidated over the years. Party leaders are content with most of their MPs and therefore feel less need to purge incumbents from their party lists prior to elections. Declining non-electoral turnover rates may therefore indicate a strengthening of party leadership. Two, the decline in non-electoral incumbent turnover rates could, however, also mean that party leaders were no longer able to deselect incumbents in 2014 to the same degree they were in 2004 because incumbents have found ways to influence the candidate selection process in their favour. Declining non-electoral incumbent turnover rates may indicate, in fact, a weakening of party leaderships.

In short, we need to gain a better understanding of why non-electoral turnover has decreased dramatically in Indonesia over the years. Is this a sign for the institutionalization of Indonesian political parties? Have party leaders managed to streamline party apparatuses and establish a pool of loyal and electable MPs that make pre-election purges unnecessary? Alternatively, is the decline of non-electoral incumbent turnover indicating that a class of professional MPs has emerged that has managed to co-opt their party leaders?

The decline in non-electoral incumbent turnover may also have been caused by aforementioned changes in the electoral system. Open-list electoral systems, for instance, may increase the risk for party leaders to de-select incumbents because citizens look at candidates' personal reputation rather than their party label in open-list electoral systems (Carey and Shugart 1995, 418; Gouglas et al. 2018, 11). Future research will not only have to 
examine party's candidate selection criteria but also whether the shift from a closed- to an open-list system has shaped party leaders’ strategy with regard to incumbent de-selection. Indonesia may turn out to be a case where the introduction of an open-list system for the sake of increasing accountability and a deepening of democracy has had the exact opposite effect, namely to discourage party leaders from de-selecting incumbents. In other words, since the introduction of an open-party list system, party leaders have played it safe by selecting more incumbents when putting together their respective party’s candidate lists.

There is not only variance in non-electoral incumbent turnover across time but our research also showed that non-electoral incumbent turnover differed between parties in a given election year. The causes for this variance need to be examined in future research too. Some parties such as the PPP had consistently high non-electoral turnover rates across election years, while there were parties such as the PKS that have had low non-electoral turnover figures since 2004.

Future research will have to identify the reasons for these differences across parties within a given election year. Arguably, the formative years of Indonesian parties play an important role in non-electoral incumbent turnover rates. For instance, the PPP was established after Suharto forced Islamic parties to merge into a single party in 1973. The amalgam of different interests began to show cracks immediately after the democratic opening in 1998. The PPP has been struggling to overcome infighting and party internal rifts ever since. The PPP's high non-electoral turnover rates over the past election cycles may reflect these internal tensions. The PKS, in contrast, is the only party in Indonesia that grew out of a class-based social movement. Arguably, this is why the PKS is also one of the most consolidated parties with a strong internal power structure tilted in favour of the party leadership (Buehler 2013). The low non-electoral incumbent turnover may be the result of PKS’ comparatively consolidated party structures. In other words, the differences in nonelectoral turnover figures between parties may indicate that some parties are more consolidated than others.

In short, the candidate selection process in general and incumbent deselection in particular deserve more attention in order to better understand the perpetuation and renewal of political elites in Indonesia. Such research will not only illuminate incumbent turnover in Indonesia but will contribute to debates on whether or not party leaders play an important gatekeeper function in the renewal and perpetuation of elites, a question that is currently being discussed in the broader literature on democratisation in young democracies (Chandra 2016, 3). Recent research on incumbent turnover in Western Europe has identified the role 
parties play in incumbent turnover as "the most fundamental question" to be addressed in future studies (Gouglas et al. 2017, 21).

A comparison of official party rules regarding the candidate selection process (Juklak - Petunjuk Pelaksanaan) is a logical first step in examining the role parties play in incumbent turnover in Indonesia. Between 2010 and 2014, we tried for months on end to obtain these Juklak from all major parties in Indonesia for all election cycles since 1999. This proved to be difficult as parties claimed that they no longer have copies of these rules or were outright hostile when asked to share these rules and regulations. After four years, we managed to obtain only a fraction of the candidate nomination rules needed for such a study.

The difficulties we encountered when trying to gather these documents suggests that party leaders have no interest in a transparent nomination process. Arguably, this is because these official rules are frequently ignored and violated during backroom negotiations pertaining to candidate selection prior to elections. Our difficulties to obtain even the formal rules regulating this process nevertheless shows the importance of examining in more depth the role of party leaders in incumbent turnover in Indonesia.

\section{5.ii Incumbent turnover due to failure to get re-elected}

Finally, there are various questions regarding the role of the Indonesian electorate in incumbent turnover that need to be addressed in future research. First, existing scholarship has argued that electoral volatility may play an important role in incumbent turnover. The higher electoral volatility - that is "the net change within the electoral party system resulting from individual vote transfers” (Pedersen 1979, 1475) - the higher the chances that incumbents are voted out of office due to partisan defeat (Heinsohn and Freitag 2012, 364).

The impact of electoral volatility on incumbent turnover interacts with the type of electoral system as well as district magnitude. Electoral volatility is more likely to increase incumbent turnover in single-member district (SMD) systems than in proportional representation systems (PR). Furthermore, electoral volatility is more of a threat to incumbents in political systems with low electoral district magnitudes than in systems with high electoral district magnitudes (Matland and Studlar 2004, 95). At first sight, this does not seem to play much of a role in Indonesia's incumbent turnover. In Indonesia, electoral volatility has remained fairly stable since the first election was held in 1999, as shown in Table 3. It is therefore unlikely to play much of a role in overall incumbent turnover rates. ${ }^{16}$ Likewise, district magnitudes have also remained relatively stable throughout the years, despite lobbying efforts from larger parties to reduce the size of districts (O’Rourke 2012, 2). However, future research will have to examine whether electoral volatility at the party level 
has had an impact on incumbent turnover. In other words, have parties that lost a lot of votes from one election cycle to another also lost a lot of incumbents, or did incumbents survive such "vote transfers" from one party to another relatively unscathed?

Future research will also have to compare the role of voters with regard to incumbent turnover rates across the different electoral systems that Indonesia has had in place since 1999. Incumbent turnover through intrapartisan defeat is more likely in PR systems that rely on open party list systems than in PR systems that are based on closed-party list systems (Matland and Studlar 2004, 93). ${ }^{17}$ Open party list systems of the kind introduced in Indonesia in 2009 are said to increase intraparty competition. Open party list systems force candidates to campaign against co-partisans and members from other parties because only the number of preference votes, not party list rank, decides whether or not a candidate will receive a seat in parliament.

Our data presented in Table 1 showed that there is no such trend in Indonesia. In fact, the percentage of incumbents who failed to get re-elected due to partisan defeat has steadily increased over the years. There has been an increase in incumbent turnover through partisan defeat and a decline in incumbent turnover through intrapartisan defeat, despite the shift to an open-list PR electoral system.

There may be several reasons why partisan defeat has replaced intrapartisan defeat as the main reason for electoral incumbent turnover, despite the shift from a closed list party system to an open party list system. One, party labels continue to matter in Indonesia, even in an open party list system. Since candidates cannot self-nominate under Indonesian election rules, party leaders nominate candidates. In addition, party votes matter for the overall seat allocation. There are therefore incentives for incumbents and newcomers alike to compete under the same party label. Two, despite a switch from a closed party list system to an open party list system, Indonesian voters rarely disturb party lists. In the 2004 elections, $98.6 \%$ of all elected candidates had been listed on one of the top three party list ranks. ${ }^{18}$ In the 2009 elections, the first under an open party list system, $90.4 \%$ of all candidates who won a seat in parliament came from one of the top three party list ranks. In 2014, 83.6\% of all successful candidates came from the top three party list ranks. In other words, while Indonesian voters have begun to disturb party lists and vote for a growing number of candidates ranked fourth or lower on party lists, the overwhelming majority of votes continue to be cast for candidates at the very top of party lists, as shown in Table 4.

These figures suggest that Indonesian voters rather vote for a top ranked candidate from another party than a lower ranked candidate from the same party. This may explain why 
partisan defeat has replaced intrapartisan defeat as the main reason for electoral incumbent turnover. However, voter behaviour seems also rather complex with regard to top three ranked candidates. Comparing the 2009 and 2004 elections, we found that after Indonesia switched to an open party list system in 2009, incumbents attracted more preference votes than non-incumbents, but only if they were first or third ranked on party lists. Comparing the 2014 and 2009 elections, we found that list disturbance became more pronounced. Fewer voters supported top three ranked candidates. However, we also found that incumbents ranked second on party lists accumulated more preference votes in 2014 than in 2009. Finally, comparing the 2014 and the 2004 elections, we found that voters disturbed party lists to a higher degree in 2014 than in 2004. However, in 2014 voters did not pull away from first and second ranked candidates if they were incumbents.

The higher levels of preference votes and a shift of preference votes away from candidates ranked at the top of party lists we detected is in line with the literature on the effects of open party list systems on voter behaviour. Open party list systems are said to encourage preference votes and list disturbance. However, our findings also suggest that these effects are sometimes neutralized by incumbency. As shown above in Table 4, the majority of candidates elected into parliament were from the top three ranks on party lists. Future research will have to examine why voters continue to vote for top ranked candidates despite the fact that the electoral system adopted in 2009 would actually allow them to vote for lower ranked candidates. In other words, the decline in incumbent turnover rates due to co-partisan defeat is not in line with turnover rates in other countries that switched from a closed-list to an open-list system. Future research therefore needs to examine how in Indonesia incumbency mitigates the impact of dynamics usually associated with open-list systems.

The picture is complicated by the fact that a potential interaction effect between incumbency and party list rank is not stable across ranks and election years, as shown above. In light of these findings, future research on incumbent turnover in Indonesia should investigate further why there is an interaction effect between incumbency and party list rank for certain list ranks in certain election years. Is it a positive track-record, face recognition, proximity to party leaders, or a combination of these that allow top ranked newcomers to profit from their list ranking compared to newcomers with the same party list ranks? Likewise, future research will have to address why top ranked incumbents lost in certain years while they attracted more votes than lower ranked incumbents in other years. Were voters content with the politics and policymaking of incumbents listed at the top of party lists 
in 2009 but not in 2014? Did party leaders support third ranked incumbents but not second ranked incumbents in 2009?

\section{Consequences of high incumbent turnover}

While this article has mainly identified research questions regarding the causes of incumbent turnover, future research will also have to examine the consequences of Indonesia's high incumbency turnover rates. This is especially important with regard to the quality of democracy and policymaking. Total incumbent turnover, consisting of non-electoral and electoral turnover rates, was 69.9\% in 2004, 72.2\% in 2009 and 58\% in 2014. In other words, total incumbent turnover figures have remained extraordinarily high in Indonesia over the past 20 years.

Indonesia’s high total incumbent turnover rates are usually talked about in positive terms as they are understood as indicators for the dynamism and vibrancy of Indonesia's democratisation process (Hicken and Kuhonta 2011, 586; Case 2015, 259). However, it is far from clear whether the country's high incumbent turnover rates are a reason for optimism. The existing literature on incumbent turnover rates in consolidated democracies warns of both too high and too low incumbent turnover rates.

If incumbent turnover rates are too high, the quality of lawmaking may suffer because of a lack of experience and institutional knowledge among lawmakers (Luce 1924, 358) High turnover rates, in other words, may "preclude consistent, thoughtful decision making” (Moncrief et al. 2004, 357). In addition, high turnover rates may also weaken the "watchdog functions” of parliaments (Rosenthal 1974, 609).

While high incumbent turnover rates may weaken the quality of lawmaking and horizontal accountability (Bell and Price 1975; Miquel and Snyder 2006), low incumbent turnover rates are equally undesirable. If there is very little circulation of parliamentarians, there is a risk that a class of professional politicians emerges that increasingly rules in its own interest rather than that of the public. Low incumbent turnover rates, in other words, may undermine accountability too. Furthermore, a parliament in which only few members are replaced from one election to another also prevents new political groups from entering formal politics. This may lead to growing frustration among the electorate and a loss of legitimacy for the national assembly. ${ }^{19}$

The existing literature mentions an incumbent turnover rate of $20-30 \%$ from one election to another as ideal for the functioning of a parliament and the consolidation of democracy (Best 2008, 101; Blondel 1973, 85; Cotta and Best 2000, 505, Crowther and 
Matonyte 2007, 291). While Indonesia's extremely high turnover rates certainly suggest a reexamination of the argument that oligarchs and entrenched elites dominate Indonesian politics (Winters 2011; Hadiz and Robison 2013), a more cautious assessment of the country's high turnover rates are in order in light of our findings. Rather than a sign for a healthy replacement of old elites with newcomers, Indonesia’s high turnover may be an important explanation for the low productivity, weak oversight function and abysmal quality of lawmaking the Indonesian parliament has been criticized for (Adiputri 2015; Ziegenhain 2008b, 169). In other words, the weak law-making capacity of Indonesia's parliament may be a consequence of a lack of experience and poor institutional memory as a result of high incumbent turnover rates.

\section{Conclusion}

This article has provided the first systematic account of incumbent turnover in Indonesia since 1999, and has identified various avenues for future research. While we here examined incumbent turnover at the party level, most of the avenues for future research identified above can only be addressed by studying incumbent turnover at the individual level. Concretely, the backgrounds of successful and unsuccessful incumbents on the ballot list need to be compared to answer such questions. For instance, do deselected incumbents have similar political careers? Are incumbents wealthier than newcomers? Did successful incumbents stand out in the policymaking process by suggesting innovative laws or populist agendas? Do incumbents who are voted out share a similar socio-economic background? Sebastian Dettman, Thomas B. Pepinsky and Jan H. Pierskalla's 2017 contribution is an important step towards studying incumbent turnover at the candidate level. However, more research needs to be conducted on candidate characteristics such as socio-economic background, links to the New Order dictatorship and political dynasties in order to obtain a better sense if, and if so how, incumbent turnover contributes to elite renewal in the world's third largest democracy. Most importantly, future research will have to differentiate between newcomers and re-entering MPs to gain a better understanding of elite renewal and not only elite circulation in the world's largest democracy.

A close examination of the biographies and socio-economic background of incumbents and newcomers is also necessary since the circulation of elites and the composition of elites are not the same as mentioned before. It may well be the case that incumbents are replaced by figures of similar background and socio-economic standing rather 
than by genuinely “new” interest groups or classes. The oligarchy thesis that stresses elite continuity above all, would then still hold, despite Indonesia's high incumbent turnover rates.

In other words, if MPs are merely recycled, rather than renewed, arguably Indonesia's political system is then more stable than the high incumbency turnover rates would suggest. On the other hand, if high incumbent turnover rates also mean high newcomer rates, Indonesia is then more democratic than accounts of oligarchic tendencies in Indonesian politics imply.

Furthermore, our study also showed the necessity for more studies on incumbent turnover in new democracies in general. Most new democracies are characterized by weakly institutionalized political parties, volatile party systems, relatively high levels of party switching by candidates, money politics and vote-buying instead of programmatic political agendas, as well as endemic and systemic corruption. Our paper has hinted at how these characteristics may lead to incumbent turnover dynamics very different from the consolidated democracies in North America and Western Europe, the subject of most research on incumbent turnover.

\section{Bibliography}

Abel, François, and Emiliano Grossman. 2015. "How to Define Legislative Turnover? The Incidence of Measures of Renewal and Levels of Analysis." The Journal of Legislative Studies 21(4): 457-475.

Adiputri, Ratih D. 2015. "Parliamentary Reforms through Parliamentary Procedure: A Lesson-learnt from the Indonesian Parliament,” Paper presented at the 12th Workshop of Parliamentary Scholars and Parliamentarians Wroxton College, Oxfordshire, UK, 25-26 July.

Bell, Charles Gordon, and Charles M. Price. 1975. The First Term. Beverly Hills: Sage. Best, Heinrich, Christopher Hausmann and Karl Schmitt. 2000. "Challenges, Failures and Final Success: The Winding Path of German Parliamentary Leadership Groups Towards a Structurally Integrated Elite, 1848-1999.” In Parliamentary Representatives in Europe, 1848-2000: Legislative Recruitment and Careers in Eleven European Countries, edited by Heinrich Best and Maurizio Cotta, 138-195. Oxford: Oxford University Press.

Best, Heinrich. 2008. "New Challenges, New Elites? Changes in the Recruitment and Career Patterns of European Representative Elites." International Studies in Sociology and Social Anthropology 107: 85-113.

Blondel, Jean. 1973. Comparative Legislatures. Englewood Cliffs, NJ: Prentice Hall. 
Borchert, Jens. 2011. "Individual Ambition and Institutional Opportunity: A Conceptual Approach to Political Careers in Multi-Level Systems." Regional and Federal Studies 21(2): $117-140$

Buehler, Michael. 2013. "Revisiting the Inclusion-Moderation Thesis in The Context of Decentralized Institutions: The Behavior of Indonesia’s Prosperous Justice Party in National and Local Politics." Party Politics 19(2): 210-229.

Carey John M. and Matthew S. Shugart. 1995. “Incentives to Cultivate a Personal Vote: A Rank Ordering of Electoral Formulas.” Electoral Studies 14(4): 417-439

Case, William. 2015. “Democracy, Hybridity, and Accountability in Southeast Asia’s Legislatures.” In Routledge Handbook of Southeast Asian Democratization, edited by William Case, 250-267. London: Routledge.

Chandra, Kanchan. 2016. “Prologue.” In Democratic Dynasties: State, Party and Family in Contemporary Indian Politics, edited by Kanchan Chandra, 1-11. Cambridge: Cambridge University Press.

Cotta, Maurizio, and Heinrich Best. 2000. "Between Professionalization and Democratization: A Synoptic View on the Making of the European Representative.” In Parliamentary Representatives in Europe 1848-2000: Legislative Recruitment and Careers in Eleven European Countries, edited by Heinrich Best and Maurizio Cotta, 493-526. Oxford: Oxford University Press.

Crowther, William E., and Irmina Matonyte. 2007. "Parliamentary Elites as a Democratic Thermometer: Estonia, Lithuania and Moldova Compared.” Communist and Post-Communist Studies 40: 281-299.

Dettman, Sebastian, Thomas B. Pepinsky and Jan H. Pierskalla. 2017. "Incumbency Advantage and Candidate Characteristics in Open-List Proportional Representation Systems: Evidence from Indonesia." Electoral Studies 48: 111-120.

Gouglas, Athanassios, Bart Maddens and Marleen Brans. 2018. "Determinants of Legislative Turnover in Western Europe, 1945-2015." European Journal of Political Research 57 (3): 637-661.

Hadiz, Vedi R., and Richard Robison. 2013. "The Political Economy of Oligarchy and the Reorganization of Power in Indonesia." Indonesia 96(1): 35-57.

Hazan, Reuven Y., and Gideon Rahat. 2006. "The Influence of Candidate Selection Methods on Legislatures and Legislators: Theoretical Propositions, Methodological Suggestions and Empirical Evidence." The Journal of Legislative Studies 12(3-4): 366-385. 
Heinsohn, Till, and Markus Freitag. 2012. "Institutional Foundations of Legislative Turnover: A Comparative Analysis of the Swiss Cantons.” Swiss Political Science Review 18 (3): 352370.

Hicken, Allen. 2006. "Stuck in the Mud: Parties and Party Systems in Democratic Southeast Asia." Taiwan Journal of Democracy 2(2): 23-46.

Hicken, Allen, and Erik Martínez Kuhonta. 2011. "Shadows from the Past: Party System Institutionalization in Asia." Comparative Political Studies 44 (5): 572-597.

King, Gary. 1991. "Constituency Service and Incumbency Advantage." British Journal of Political Science 21 (1): 119-128.

Kuklys, M. 2013. "Legislative Turnover in the Baltics after 1990: Why is It so High and What are the Implications?” Baltic Journal of Political Science 2: 29-49.

Luce, Robert. 1924. Legislative Assemblies. Boston: Houghton Mifflin.

Matland, Richard E., and Donley T. Studlar. 2004. "Determinants of legislative turnover: a cross-national analysis." British Journal of Political Science 34 (1): 87-108.

Mietzner, Marcus. 2009. “Indonesia and the Pitfalls of Low-quality Democracy: A Case Study of the Gubernatorial Elections in North Sulawesi.” In Democratization in Post-Suharto Indonesia, edited by Marco Bunte and Andreas Ufen, 124-150. New York: Routledge. Miquel, Gerard Padró I., and James M. Snyder. 2006. “Legislative Effectiveness and Legislative Careers.” Legislative Studies Quarterly 31(3): 347-381.

Moncrief, Gary F., Richard G. Niemi and Lynda W. Powell. 2004. "Time, Term Limits, and Turnover: Trends in Membership Stability in US State Legislatures." Legislative Studies Quarterly 29(3): 357-381.

Nehru, Vikram and Nadia Bulkin. 2013. "How Indonesia’s 2014 Elections Will Work,” Carnegie Endowment for International Peace, October 24.

https://carnegieendowment.org/2013/10/24/how-indonesia-s-2014-elections-will-work-pub$\underline{53416}$

Norris, Pippa. 1993. “Conclusion: Comparative Legislative Recruitment in Western Democracies.” In Gender and Party Politics, edited by Joni Lovenduski and Pippa Norris, 309-330. London: Sage.

O'Brien, Diana Z., and Yael Shomer. 2013. "A Cross-National Analysis of Party Switching." Legislative Studies Quarterly 38 (1): 111-141.

O’Rourke, Kevin. 2012. "Parliament Passed the Revised Legislative Election Law on 12 April,” Reformasi: Weekly Review. 13 April. 
Pedersen, Mogens N. 1979. "The Dynamics of European Party Systems: Changing Patterns of Electoral Volatility." European Journal of Political Research 7 (1): 1-26.

Rosenthal, Alan. 1974. "Turnover in State Legislatures." American Journal of Political Science 18: 609-616.

Sherlock, Stephen. 2007. "Parliamentary Indicators: Indonesia House of Representatives (DPR) House of Regional Representatives (DPD).” Jakarta: The World Bank Institute. Accessed 8 May 2017.

https://siteresources.worldbank.org/PSGLP/Resources/ParliamentaryIndicatorsIndonesia.pdf Sherlock, Stephen. 2004. The 2004 Indonesian Elections: How the System Works and what Parties Stand For. Canberra: Centre for Democratic Institutions. Accessed 11 May 2018. https://pdfs.semanticscholar.org/9a52/bc9307cc67e0d8e9fea495904f8628b65250.pdf Tomsa, Dirk. 2010. “The Indonesian Party System After the 2009 Elections: Towards Stability?” In Problems of Democratisation in Indonesia: Elections, Institutions and Society, edited by Edward Aspinall and Marcus Mietzner, 141-59. Singapore: ISEAS.

Winters, Jeffrey. 2011. Oligarchy. Cambridge: Cambridge University Press.

Ziegenhain, Patrick. 2008a. "The Indonesian Legislature and Its Impact on Democratic Consolidation.” In Democratization in Post-Suharto Indonesia, edited by Marco Bunte and Andreas Ufen, 33-52. London: Routledge.

Ziegenhain, Patrick. 2008b. The Indonesian Parliament and Democratization. Singapore: ISEAS. 
Figure 1: Causes of Incumbent Turnover Matrix

\begin{tabular}{|l|l|l|}
\hline & Supply-side causes & Demand-side causes \\
\hline Non-electoral causes & - Death & - De-selection by party \\
& - Forced resignation & \\
& - Voluntary exit & \\
\hline Electoral causes & & - Failure to get re-elected \\
\hline
\end{tabular}


Table 1 Incumbent Turnover, 2004-2014, by party

Table 2: Electoral results of party switchers

\begin{tabular}{|c|c|c|c|}
\hline Election & $\begin{array}{c}\text { Intrapartisan } \\
\text { Defeat }\end{array}$ & $\begin{array}{c}\text { Partisan } \\
\text { Defeat }\end{array}$ & Elected \\
\hline 2004 & 0 & 7 & 1 \\
\hline 2009 & 12 & 12 & 3 \\
\hline 2014 & 2 & 6 & 2 \\
\hline
\end{tabular}

Source: authors' calculation based on National Electoral Commission data

Table 3: Electoral Volatility in Indonesia since 1999

\begin{tabular}{|l|l|l|l|}
\hline $\begin{array}{l}\text { Electoral volatility } \\
\text { between... }\end{array}$ & 2004 and 1999 & 2009 and 2004 & 2014 and 2009 \\
\hline & $29 \%$ & $30 \%$ & $27 \%$ \\
\hline
\end{tabular}

Source: authors' calculation based on National Electoral Commission data

Table 4: Party list rank of successful candidates, by legislative period 


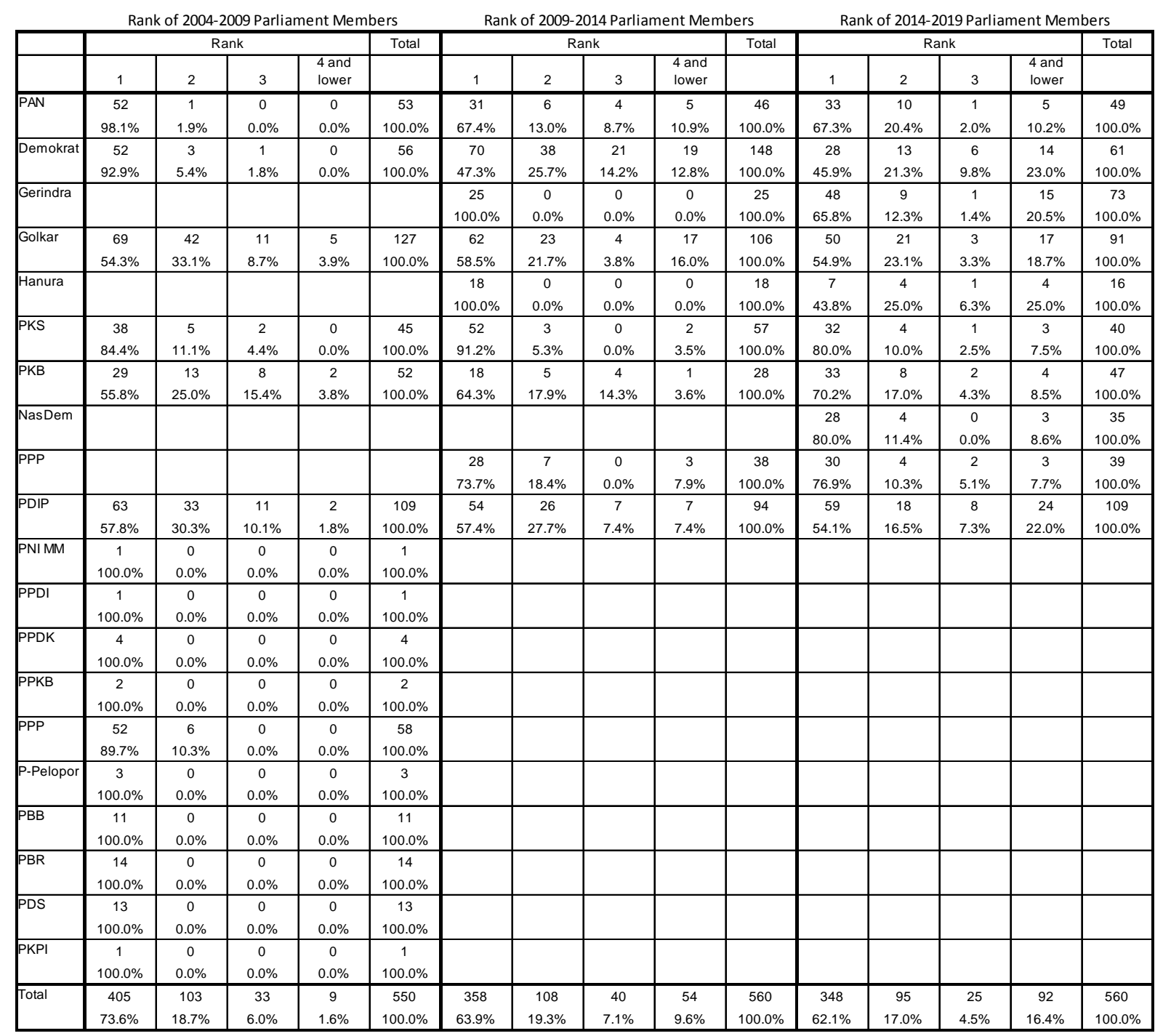

\footnotetext{
${ }^{1}$ Research for this article was made possible by a SOAS seedcorn fund. Thank you.

${ }^{2}$ We have compiled data on first-time legislators and are planning to report our findings in a separate paper.

${ }^{3}$ The latter is increasingly common because there is a two-term limit for Indonesian executive government posts. Many two-time governors or district heads then re-enter politics as legislators at the end of their term to remain "in the game" and close to rent-seeking opportunities.

${ }^{4}$ Emphasis in the original.

${ }^{5}$ We thank Emiliano Grossman, Till Heinsohn, Gary Moncrief, and Shana Warren for their helpful advice.

${ }^{6}$ At the time this article went to press the official MP list for the 2019-2024 had yet to be released. We therefore did not include it in this article.

${ }^{7}$ By consolidation we mean that a stable number of effective parties crystallized by this point (Tomsa 2010).

${ }^{8}$ There were only 462 seats available for elected candidates in the 1999-2004 parliament because there were still seats reserved for the armed forces as a legacy of the New Order dictatorship.

${ }^{9}$ We thank an anonymous reviewer for alerting us of this possibility.

${ }^{10}$ In September 2018, the Indonesian Supreme Court ruled that corruption convicts were allowed to run for a seat in the 2019 legislative elections. Subsequently, several political parties nominated corruption convicts as candidates, including President Widodo's PDI-P.

${ }^{11}$ In Indonesia, parliamentary support services improved until 2009 and have since stagnated at that level.

Conversation with Frank Feulner, Parliamentary Development Specialist, 9 April 2018.

${ }^{12}$ We thank Emiliano Grossman for his comments.
} 


\footnotetext{
${ }^{13}$ Occasionally, party leaders successfully circumvented this rule. Eventually, 92 of a total of 462 MPs in the 1999-2004 parliament represented a district they had not been running in. We thank Marcus Mietzner for this information. See also Sherlock 2004, 7.

${ }^{14}$ In 2009, many voters were confused because they remembered that they had been allowed to tick two boxes in 2004. This confusion apparently accounted for $14 \%$ invalid votes in the 2009 elections. We thank Marcus Mietzner for pointing this out.

${ }^{15}$ Our data on this issue is incomplete. However, prior to the 2004 elections, only three incumbents died in office.

${ }^{16}$ Electoral volatility explains incumbent turnover rates at the party level when compared across election cycles to some degree.

${ }^{17}$ Similarly, single transferable vote systems (STV) show higher turnover due to intrapartisan defeat than single non-transferable vote (SNTV) systems (Matland and Studlar 2004, 93).

${ }^{18}$ How remote the chances of getting elected on preference votes alone were in the 2004 elections is shown by the fact that only two out of 7,756 candidates running for the 550 national parliamentary seats accumulated enough votes to pass the divisor. The other 548 successful candidates were allocated a seat solely based on their party list rank.

${ }^{19}$ Email conversation with Till Heinsohn, 11 May 2017.
} 